\title{
Method and Strategy of the Universitas Negeri Semarang in Overcoming Student Radicalism
}

\author{
Ali Masyhar ${ }^{1}$, Muhammad Azil Maskur ${ }^{2}$ \\ \{ali_masyhar@mail.unnes.ac.id\} \\ ${ }^{1,2}$ Faculty of Law, Universitas Negeri Semarang, Semarang, Indonesia
}

\begin{abstract}
This article intends to study and analyze anti-radicalization methods and strategies at Universitas Negeri Semarang (UNNES) and study and explore appropriate policy programs to close the gap for radical understanding to enter UNNES. UNNES, as an educational institution, also cannot escape the potential of radicalism's target in spreading its ideology. To anticipate the entry of a radicalism doctrine - both radical right and left radical - UNNES has issued several policies. Specifically related to ethics and rules on campus, the Chancellor's Regulation was explained, namely Rector's Regulation No. 44 of 2018 concerning UNNES Student Ethics and Rules (is a substitute for Rector's Regulation No. 19 of 2016 regarding UNNES Student Ethics and Rules). Regarding student communication on social media, UNNES issued Chancellor Regulation No. 11 of 2019 concerning Management of Digital Reputation Synergy of UNNES. To support the Student Ethics and Code of Conduct, a Student Ethics Board was formed, consisting of legal experts and Vice Deans for Student Affairs at UNNES. The UNNES Digital Reputation Synergy Team (SINERGIS) was formed to enforce the rules on Digital Reputation Synergy Management. Specifically, in anticipating radicalism, in 2018, the UNNES Anti-Radical Task Force was formed. Also, UNNES has a Center for Anti-Radicalism and Terrorism Studies at the Faculty of Law, UNNES.
\end{abstract}

Keywords: Student Radicalism, Method and Strategy Antiradicalism

\section{Introduction}

Radicalism and extremism are ideological diseases that have lately become a problem for humankind throughout the world. In the Indonesian social order, radicalism/extremism can manifest in the form of the right extreme and left extreme. [1] In the right height, it is often addressed to those who are religious-oriented with intolerant ideas, unable to accept differences of understanding with other religions, even fellow religions. This category includes those who commit to terrorism acts by bombing in the name of jihad. While the left extreme is pinned to those, who are Marxist, Leninism and socialism-oriented, this left direction often wants to clash elements of the nation's people with one another. Either the right or left extreme eventually both claim and question the Pancasila as a state foundation, the 1945 Constitution, and the Unitary State of the Republic of Indonesia.

Nationally, radicalism and terrorism have increased. Compared to data in 2017, radicalism and terrorism in 2018 increased by $42 \%$. In 2017 there were 12 cases of radicalism and terrorism, while in 2018, it increased to 2018. Throughout 2018 there were 396 terrorists arrested. [2] The surprising fact is that the perpetrators are generally young people.

It was associated with the potential for the rise of left extreme ideology/communism. [3], [4] [5], [6] It still becomes a polemic. Some figures stated that communism as an ism or ideology is not easy to eradicate, as it will even continue to escalate [7] Therefore, as an effort to anticipate, the State must take tactical steps to avoid being missed. 


\section{Methods}

\subsection{Research Specifications and Approach Method}

This Research used sociological/empirical/ nondoctrinal research methods, although it still based on the normative analysis. This Research was due to comprehensive legal Research that constantly synergizes various scientific disciplines. [8]

\subsection{Data collection technique}

Literature/document study and interviews are used in this Research.

a. Literature/document study

This technique was directed to obtain secondary data from primary, secondary, and non-legal material. The tool used for the study of documents is the documentation form. [9]

b. Interview

An interview is a process of obtaining information for research purposes by way of question and answers in face-to-face interaction between the interviewer and the interviewee, both with or without using interview guides [10] Kerlinger formulated an interview as a situation of interpersonal role in a face to face when someone-interviewer-asks questions designed to obtain answers relevant to the research problem, to someone as the interviewee [11] Interviews were conducted with stakeholders of Universitas Negeri Semarang.

\subsection{Data Presentation and Analysis}

The exact method for understanding the meaning of texts is hermeneutics [12] Legal hermeneutics is a method of interpretation of a legal text, statutory regulations, and the results of legal studies.[13] It includes an understanding of one's perception of doctrine and outlook on life.

\section{Result and Discussion}

\subsection{Preventive Measures}

Due to the phenomenon of the spread of radicalism and terrorism, the government has held several steps, mainly the penal measures. The issuance of Law No. 5 of 2018 on Amendment to Law Number 15 of 2003 on Establishment of Government Regulations in lieu of Law Number 1 of 2002 on Eradication of Terrorism Criminal Acts into Laws, is expected to be a strategic measure in mitigating the massive terrorist movement and its spread. Effective and efficient preventive measures, however, have not yet been seen. Therefore, this research is a means to produce a blueprint for overcoming the spread of radicals who have metamorphosed and adapted to the times, particularly the use of electronic media, especially on the UNNES campus.

There is a saying that "prevention is better than cure" seems appropriate to be applied in tackling radicalism. The prevention of radicalism will be better, if before the penal measure (repressive/treatment) is taken, first try alternative non-penal measures (preventive). This is because the factors that drive extremist/radicalized actions are more increased in the nonpenal realm.

The $8^{\text {th }}$ United Nations Congress in document A/CONF.144/L.3 identified conducive factors that could lead to crime and extremism including poverty, unemployment, illiteracy, the absence/lack of adequate housing and education as well as unsuitable training system. Thus in tackling radicalism movement, efforts should be taken to eliminate the criminogen factor. This is where the effort to ward it off, becomes so strategic [14]

Prevention/deterrence is one of the tasks of the BNPT (as mandated in Presidential Regulation No. 46 of 2010 on the National Counter Terrorism Agency), in addition to the duty of repression (legal approach, including penal). Prevention efforts are carried out through a persuasive approach [15] Repressive efforts gradually began to be ruled out. As BNPT 
acknowledges, military and violent approaches are not the right answer. The harder physical actions are carried out on radical groups, the more they become militants

According to the author, the prevention of radical movements in society must be carried out simultaneously between the repressive and preventive approaches. The repressive approach must also be accompanied by non-penal efforts [16] [17] [18] [19] And an effective way to prevent/deter is to eliminate the triggering factors as described above. For this reason, efforts to counter radicalism/terrorism are very effective when simultaneously linked to religion, ideology (new fanaticism), eliminating the gap between rich and poor, opening communication taps between the people and the government, reducing the explosion of rapidly increased population, preparing employment (eliminating unemployment), anticipating the generation of frustration, and preparing the comfort of people's lives.

\subsection{UNNES Strategic Measures}

Almost certainly, all lines today are not sterile from the target of extremism/radicalism, including Educational institutions. UNNES also did not escape the target of radicalists in developing their doctrines. Some ideologies, both right and left one, have begun to quietly and gradually break into the students' thinking. Intolerant attitude and assuming that their group is selfrighteous has penetrated the student groups. Whether we realize it or not, this kind of attitude becomes the entry to radicalism. On the other hand, aspiration and anesthetization that oneself as an "agent of change' often also leads students to start criticizing the existed establishment. It includes starting to question the effectiveness of the Pancasila, the 1945 Constitution, even the Unitary State of the Republic of Indonesia.

In order to anticipate the entry of radicalism - both right and left radical - UNNES has issued a number of policies. The policies adopted by UNNES are:

1. Rector's Regulation No. 44 of 2018 on UNNES Student Ethics and Rules.

The Rector's Regulation is a lieu of Rector's Regulation No. 19 of 2016 on UNNES Students Ethics and Rules. This policy is a central policy in managing students' ethics and rules. In essence, the Rector's Regulation contains two main things, which are student ethics and order. In the realm of ethics, UNNES students must hold a number of ethical rules consisting of

a. behave and being honest;

b. respect the rights of fellow students, lecturers, education personnel, and others;

c. speak no words and/or conduct no actions that degrae a person's humanity, threaten the safety, both physically and psychologically;

d. respect the property of others by not damaging or misusing, including goods or facilities provided by UNNES;

e. fulfill financial and other administrative obligations towards UNNES;

f. dress and behave inappropriately according to ethical manners, customs norms, and religion in participating in activities on campus

In addition to ethics, students are also guarded with equal rights, obligations and prohibitions. Among the most important prohibitions, students shall avoid the following:

a. follow activities that deviate from religious teachings, Pancasila, and the Constitution of the Unitary State of the Republic of Indonesia in 1945;

b. engaging and/or spreading radicalism and extremism;

c. involve and/or become an investigator in a prohibited organization;

d. hate speech through any media;

In order to ensure that this policy is implemented, it is also strengthened by a number of sanctions for violators. Violations are grouped in 3 categories, which are minor violations (with mild sanctions), moderate violations (threatened with moderate sanctions), and major violations (accompanied by severe sanctions). 
a. mild sanctions is the form of:

1) verbal reprimand;

2) written reprimand;

b. moderate sanctions is the form of:

1) postponement of proposal seminar, examination proposal, minithesis, thesis, and dissertation during a certain period of time;

2) their rights in student activities will be revoked within a certain period;

3) their rights in obtaining certain facilities/welfare will be revoked within a certain period of time;

4) temporary dismissal as a student (suspension) for a maximum of 2 (two) semesters;

c. severe sanctions is the form of:

1) cancellation of final project, minithesis, thesis, or dissertation;

2) revocation of title, retrieval of diploma, and withdrawal of transcript;

3) prohibition from participating in all academic activities within a certain period of time;

4) temporary dismissal as a student (suspension) for a maximum of 4 (four) semesters;

5) dismissal of student status with the right to Reference Letter of Discourse (SKPK);

6) cancellation of student status;

In order to enforce the implementation of this regulation, a Student Ethics Council was formed, which consisted of all Vice Deans for Student Affairs from each Faculty, and was chaired by someone who controlled the law. The Student Ethics Board is also assisted by the Secretariat Team.

2. Rector's Regulation No. 11 of 2019 on Management of UNNES Digital Reputation Synergy.

The Rector's Regulation is related to student communication on social media. It is not merely to organize social media communication systems for students, but also for all UNNES citizens (Lecturers, Education Personnel and Students).

Social media that are the object of monitoring the Synergistic team are:
a. Facebook;
b. Instagram;
c. Twitter;
d. Youtube;
e. Another online social platform that has multiuser and publicly displayed content.

This Rector's Regulation regulates the uploads of UNNES members by giving prohibition signs not to upload or share:
a. pornographic and pornoaction content;
b. hateful or riotous content;
c. content supporting/blaspheming participants of political contestation;
d. grievances about self, family, colleagues, leaders, units and institutions;
e. fake news or hoax; and
f. other content that falls in the category of violation of applicable law

In order to enforce the rules on Digital Reputation Synergy Management, UNNES Digital Reputation Synergy Team (SINERGIS) was formed. The SINERGIS team consists of 5 people who have competencies in:
a. Information Technology expert;
b. lawyer; and 
c. communication expert or linguist.

3. State Defense Program

Since 2016 there has been a state defense program by 6 days of education at Rindam IV Diponegoro. All new UNNES students are required to take part in the activity without exception. For students who pass it, they will obtain a state defense certificate. The certificate is one of the considerations in submitting scholarship facilities. This integrity pact program has been held since 2015 .

4. Integrity Pact

For new students UNNES, they must sign and promise the integrity pact. This integrity pact was signed and read in unison at the entrance ceremony for new students.

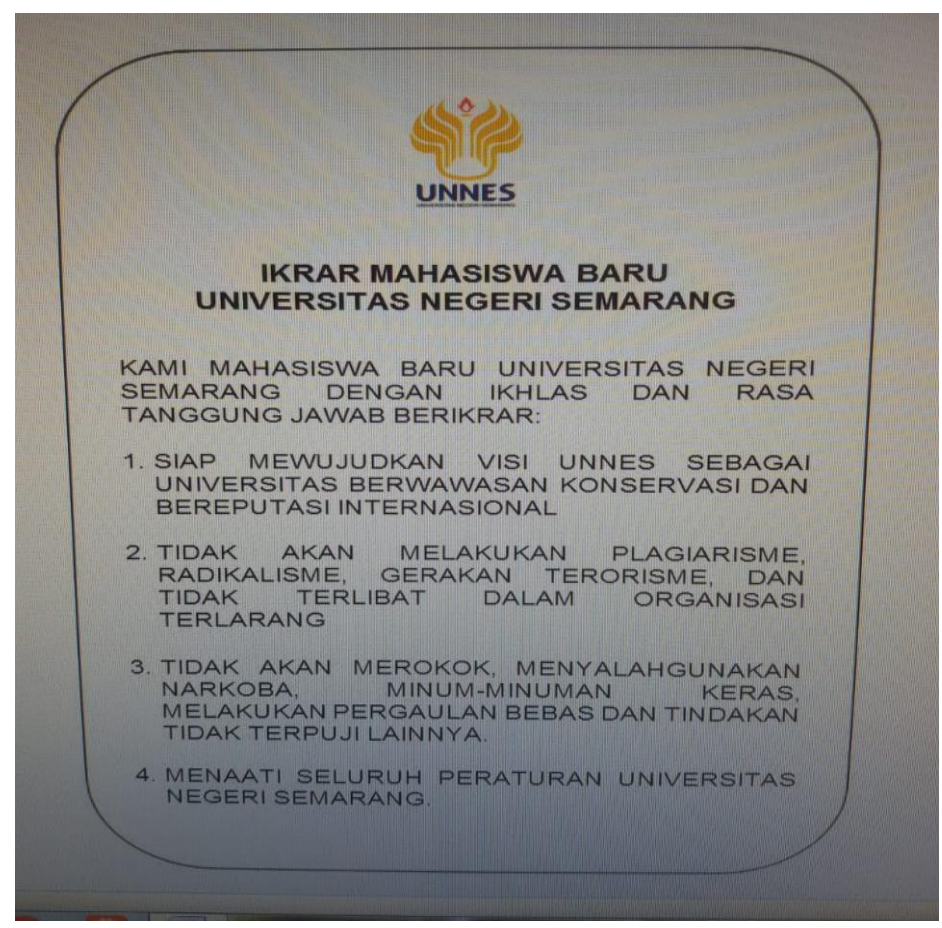

Pict. 1. Integrity Pact of UNNES New Students

5. Declaration from Semarang for Indonesia

In 2017, UNNES became a pioneer in the declaration "From Semarang for Indonesia". This activity is planting momentum to counter radicalism and extremism on campus. The activity, which was attended directly by the Minister of National Education and the Chairman of the BNPT was joined by thousands of UNNES students and representatives of universities in Semarang.

This declaration concludes by signing a large board consisting of :

a. Uphold the Republic of Indonesia based on Pancasila as the Nation's Life View and the 1945 Constitution;

b. Keeping the motto of Unity in Diversity;

c. Anti-radicalism/Terrorism;

d. Anti-drugs/lllegal Drugs;

e. Love the Motherland and Defend the Country. 


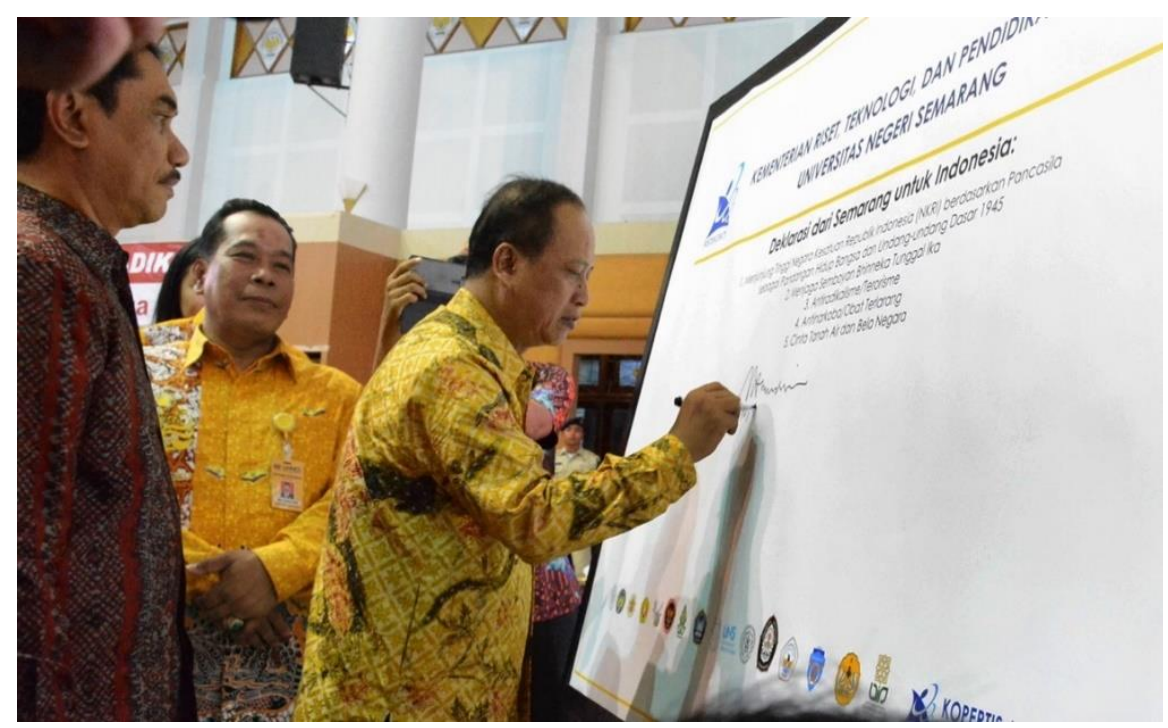

Pict. 2. Signing Declaration from Semarang for Indonesia

6. Antiradicalism Task Force

Specifically, to anticipate radicalism/terrorism, the UNNES Antiradicalism Task Force was formed in 2018. One of the main tasks is to monitor and participate in monitoring and watching over potential of existing radicalism/terrorism.

7. Establisment of the Center for the Study of Antiradicalism and Terrorism (PUSARA Terror)

UNNES also has a Center for Anti-Radicalism and Terrorism Studies at Faculty of Law UNNES, which was formed in 2016.

\section{Conclusion}

The measures taken by UNNES by preparing legal substance (a number of rector regulations) and supported by the legal structure (the existence of the Antiradicalism Task Force, Student Ethics Board and the Synergistic Team) is clearly a strategic step to tackle the possibility of radicalist ideology in UNNES. However, one main thing, in order to overcome radicalism on this campus to be optimal is that there must be a third element, which is legal culture. Antiradicalisme culture must be instilled in all UNNES. Even though the legal substance and the legal structure are already good, if it is not accompanied by a legal culture, it will certainly not be optimal.

\section{References}

[1] Kim, D. S. (2016). Communist and Post-Communist Studies The rise of European right radicalism: The case of Jobbik. Communist and Post-Communist Studies, 1-13. https://doi.org/10.1016/j.postcomstud.2016.08.001

[2] https://news.okezone.com/read/2018/12/27/337/1996594/action-terrorism- increased-42percent-396-criters- captured-in2018)

[3] Celso, A. N. (2014). Cycles of jihadist movements and the role of irrationality. Orbis, 58(2), 229-247. https://doi.org/10.1016/j.orbis.2014.02.003

[4] Kennedy-Pipe, C. (2018). 'Terrorism Studies: What We Have Forgotten and What We Now Know.' Government and Opposition, 53(2), 356-384. https://doi.org/10.1017/gov.2017.36

[5] Rapin, A.-J. (2009). Does terrorism create terror? Critical Studies on Terrorism, 2(2), 165179. https://doi.org/10.1080/17539150903010251 
[6] Victims, A. (n.d.). No Title.

[7] https://mantrasukabumi.pikiran-rakyat.com/nasional/pr-20397274/din-syamsudin-isu-pkitidak-bangkit-lagi-sengaja-digaungkan-untuk-ninabobokkan-tokoh-dan-masyarakat

[8] Barda Nawawi Arief. (1995). Normative Legal Research (An Understanding Reorienting Effort. In Upgrading the Legal Research Methodology (pp. 1-10). Purwokerto.

[9] Faisal, S. (2005). Social Research Formats. Jakarta: RajaGrafindo Persada.

[10] Burhan Bungin. (2001). Metodologi Penelitian Sosial: Format-Format Kualitatif dan Kuantitatif. Surabaya.

[11] Kerlinger, F. (1990). Behavioral Research Principles. Yogyakarta: Gadjah Mada University Press.

[12] Reeder, J., \& Reeder, J. (2018). A theory of reflection: the hermenutic circle. In Reflecting Psychoanalysis. https://doi.org/10.4324/9780429479458-4

[13] Kennedy, D. (2014). The Hermeneutic of Suspicion in Contemporary American Legal Thought. Law and Critique. https://doi.org/10.1007/s10978-014-9136-6

[14] United Nations. (1980). 8 UN Congress. Prevention of Crime and The Crime and The Treatment of Offenders.

[15] Mbai, A. (2014). Dinamika Baru Jejaring Teror di Indonesia. Jakarta: AS Production Indonesia.

[16] Holden, W. N., \& Holden, W. N. (2016). Critical Studies on Terrorism Neoliberalism and state terrorism in the Philippines: the fingerprints of Phoenix. 9153(February). https://doi.org/10.1080/17539153.2011.623401

[17] Jawad, R. (2019). A new era for social protection analysis in LMICs? A critical social policy perspective from the Middle East and North Africa region ( MENA ). World Development, 123, 104606. https://doi.org/10.1016/j.worlddev.2019.06.029

[18] Scarcella, A., Page, R., \& Furtado, V. (2016). Terrorism, radicalisation, extremism, authoritarianism and fundamentalism: A systematic review of the quality and psychometric properties of assessments. PLoS ONE, 11(12), 1-20. https://doi.org/10.1371/journal.pone.0166947

[19] Umar, A. R. M. (2010). Melacak Akar Radikalisme Islam di Indonesia. Jurnal Ilmu Sosial Dan Ilmu Politik. https://doi.org/10.1158/1541-7786.MCR-07-0324 